Iğdır Üniversitesi Fen Bilimleri Enstitüsü Dergisi, 11(Özel Sayı): 3347-3352, 2021

Journal of the Institute of Science and Technology, 11(Special Issue): 3347-3352, 2021

ISSN: 2146-0574, eISSN: 2536-4618

Bahçe Bitkileri / Horticulture

DOI: $10.21597 /$ jist.1028421

Araştırma Makalesi / Research Article

Geliş tarihi / Received: 25.11 .2021

Kabul tarihi / Accepted: 11.12.2021

To Cite: Arın L, Şahin N, Uludağ M, Kırcı AK, 2021. Determination of Emergence and Seedling Characteristics in Oneand Two-Year Seeds of Some Long-Day Onion (Allium cepa L.) Varieties. Journal of the Institute of Science and Technology, 11(Special Issue): 3347-3352.

\title{
Determination of Emergence and Seedling Characteristics in One- and Two-Year Seeds of Some Long-Day Onion (Allium cepa L.) Varieties
}

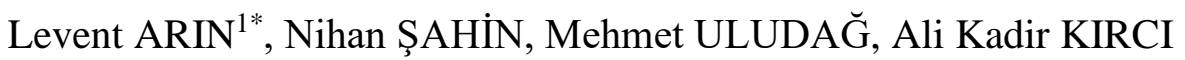

\begin{abstract}
The most important factors are the seed quality and vigor in which determine the yield and quality of vegetable production. Seed quality is affected by many factors such as seed development on the mother plant, genetic characters of species, and variety, storage conditions, etc. Onion (Allium cepa L.) has a seed that is easily deteriorating. Therefore one-year seed use is commonly recommended. In this research, which was conducted to determine the effect of the production year and variety on seed emergence and seedling properties was used one- and the two-year seed of four long-day variety (denotes A, B, C or D). As result, it was determined that the seedling morphological characters were not affected by production year and one-year seeds had a higher emergence percentage and vigor index than two-year seeds. The highest emergence rates were seen in variety D $(95.50 \%)$ for one-year seeds and in variety A $(80.00 \%)$ for two-year seeds. Among vigor indexes, the highest values were observed in variety C (2.85) for one-year seeds and variety A (2.39) for two-year seeds. Also, seed viability and viability decreasing rate were different according to varieties.
\end{abstract}

Keywords: Onion, variety, emergence, vigor, seedling

${ }^{1}$ Levent ARIN (Orcid ID: 0000-0002-0193-9912), Nihan ŞAHIN (Orcid ID: 0000-0002-3204-9082), Mehmet ULUDAĞ (Orcid ID: 0000-0002-8171-1108), Ali Kadir KIRCI (Orcid ID: 0000-0001-9126-2070) Tekirdağ Namik Kemal University, Faculty of Agriculture, Department of Horticulture, Tekirdağ, Turkey

*Sorumlu Yazar/Corresponding Author: Levent ARIN, e-mail: larin@nku.edu.tr

This article was presented orally at the 7th Seed Congress of Turkey held in Iğdır between 15-17 November 2021 


\section{INTRODUCTION}

Seed is the basic and most critical input in agriculture and is considered to be the cheapest and most crucial component compared to other inputs like fertilizers, pesticides, water etc. It is known that the most crucial input for improving the yield is the use of good-quality seeds. In the case of high-quality seed use, the expected benefit from post-sowing cultural practices could be achieved, and yield and quality could be high. The seed quality is dependent on several factors, some of which are surrounding environment during plant growth and seed development, location of seeds on plant, time of seed harvest, seed harvesting techniques, storage conditions, container and packing materials, seed treatment before sowing (Roberts, 1974; Dorna et al., 2013; Ashok et al., 2019; Brar et al., 2019; Baslar and Ilbi, 2020). After the seed completes its development on the plant, it begins to age and deteriorate at a rate that changes depending on the conditions during its life (mainly storage). The storage life of seeds is affected by factors such as cultural applications during seed production, environmental factors such as climate and soil, genetic characteristics of the variety, chemical content of the seed, and maturity level of the seed (Arin, 2018). Onion, an indispensable vegetable in kitchens and tables, is a very important economic crop used in different ways and is well known for 5000 years (Brewster, 1994; Lorenz and Maynard, 1988). Turkey ranks fifth among the onion producing countries in the world with 2200 thousand tonnes of bulb production in 68713 hectares production area (FAO, 2021). It is essential to use quality seeds for the production of onion with high yield and quality. Also, seed quality is very important in onion set and seedling production. Poor germination and low seedling vigor are the serious problems limiting the production of onion bulb and onion set. It is well-known fact that onion seeds have short storage life and due to the nature of the seed loses their viability and vigor more rapidly after harvest than the seeds of other crops unless special precautions are taken in their storage. It is possible that to maintain germinability and vigor of onion seeds for more than one-year by reducing to $6 \pm 1 \%$ of seed moisture content and storing them in moisture impervious containers at $4-15^{\circ} \mathrm{C}$ and $40-60 \%$ relative humidity (Khokhar, 2018). In addition, great differences can be seen between cultivars and seed lots in terms of storage life and germination characteristics (Khan et al., 2004; Sivasakthi and Renugadevi, 2020).

Knowledge of seed characteristics, which is the most important factor for determining yield and quality in onion, onion set or onion seedling production, is decisive in preparation of production marketing strategies. The current investigation was carried out to assess how was change emergence and seedling characters of onion depend on variety and production year.

\section{MATERIALS AND METHODS}

The one and two-years seeds of four long-day onion varieties were obtained from a national seed company in Turkey (Satisfactory and clearly inform about the storage conditions of own onion seeds could not be taken from the company that has been producing seeds of different vegetable crops for many years). Varieties were expressed with letters (A, B, C, D), years with numbers (1st, 2nd). The commercial peat recommended for the production of vegetable seedlings was used as a growing medium (Klassmann Potground-H, Doktor Tarsa Inc., Antalya, Turkey). It had pH of 6.0, EC-value of $0.40 \mathrm{dS}$ $\mathrm{m}^{-1}$, Added amount of fertilizer (NPK fertilizer 14:10:18): $1.5 \mathrm{~kg} \mathrm{~m}^{-3}$. Seeds were sown at a depth of approximately $1 \mathrm{~cm}$ in multi-cell trays with cell volume $45 \mathrm{cc}$ filled with media mentioned above. The counts were done every day and it was accepted as emergenced when the tip of cotyledon separated from soil surface and become upright (flag stage).

Mean emergence time (MET, days) was calculated according to the Formula 1. 
$\mathrm{MET}=\Sigma \mathrm{n} . \mathrm{t} / \Sigma \mathrm{n}$

$\mathrm{n}=$ number of newly emergenced seedling at time $\mathrm{t}, \mathrm{t}=$ days from sowing, and $\Sigma \mathrm{n}=$ total emergenced seedling.

Vigor Index (VI, emergence rate) was calculated according to Mereddy et al. (2000) (Formula 2).

$\mathrm{VI}=(\mathrm{G} 1 / \mathrm{D} 1)+\mathrm{G} 2 / \mathrm{D} 2)+\ldots \ldots .+(\mathrm{GL} / \mathrm{DL}) \mathrm{n}$

where G1 = number of emerged seeds (first count), D1 = number of days to first count, GL = number of emerged seeds (last count), and DL = number of days to last count.

Daily maximum and minimum temperatures were recorded during the experiment. According to the records taken for 40 days, the temperatures varied between 0 and $27^{\circ} \mathrm{C}$, and the average maximum temperature was determined as $15.9^{\circ} \mathrm{C}$ and the average minimum temperature $8.1^{\circ} \mathrm{C}$.

Forty days after sowing the seedling were carefully removed from trays and the media adhering to the roots of seedlings was washed using tap water (Figure 1). After counting the leaves and measuring the stem diameter and length, seedlings were weighed by using an electronic weighing balance. Then, dry weight of seedlings was determined by drying in an oven at $65^{\circ} \mathrm{C}$ for 24 hours.

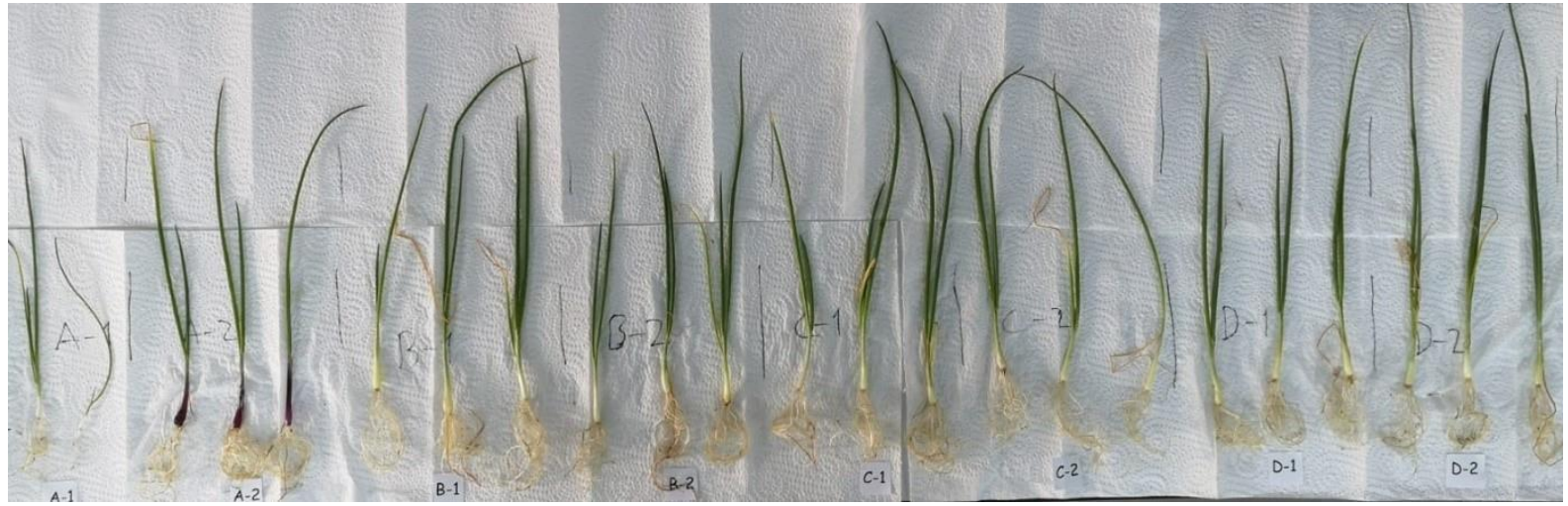

Figure 1. The seedling samples of four onion varieties

The experimental design was a randomized complete block with four replications. All data were subjected to analysis of variance (ANOVA) and mean value were compared with the LSD test. Statistic analyses are conducted in $\mathrm{R}$ statistical analysis software version 4.1.0. (R Core Team, 2021) and agricolae library (Mendiburu, 2021).

\section{RESULTS AND DISCUSSION}

While the lowest fresh weight among the varieties was seen in variety A with $40.70 \mathrm{mg}$, other varieties were in the same importance group (a). The lowest fresh and dry seedling weight was recorded in one-year seeds of A variety. In the variety-year interaction, the two-year seeds of the A variety and the one-year seeds of the $\mathrm{C}$ variety gave the highest seedling fresh and dry weight values. The highest number of leaves was determined in the two-year seeds of variety A with 3.08, while the lowest number of leaves was determined in annual seeds of the same variety.

The year did not have a significant effect on the length and diameter of the seedlings. While the length of seedling obtained from the one-year seeds of the A variety was the lowest with $25.16 \mathrm{~cm}$, the two-year seeds of the same variety were in the upper significance group (a) with $29.01 \mathrm{~cm}$. In terms of seedling diameters, the lowest value of $3.46 \mathrm{~mm}$ was recorded in the one-year seed of variety A, while the differences among other year-variety interactions were not significant (Table 1).

Differences in emergence time were not statistically significant. In terms of emergence rate, the highest value $(95.50 \%)$ was obtained from one-year seeds of D variety, while the emergence rate 
decreased with aging in varieties (except for variety A). A similar trend was observed in the case of seed vigor index, and one-year seeds of variety A and two-year seeds of variety D gave the lowest index values. The fact that one-year seeds of variety A have lower emergence rate and vigor index than twoyear seeds may have many reasons, including the mistake in the labeling of the seeds. One-year seeds of variety $\mathrm{A}$ and two-year seeds of varieties $\mathrm{C}$ and $\mathrm{D}$ did not reach the official minimum germination standards (Table 2, and Figure 2). Although the highest emergence rate was observed in the one-year seeds of the D variety, it was noteworthy that the time taken for half of the seeds to emerge in the oneyear seeds of the $C$ variety was shorter than the others (Figure 2).

Table 1. The seedling properties in one and two-year seeds of four long-day onion varieties

\begin{tabular}{|c|c|c|c|c|c|c|}
\hline & & Dry Weight (mg) & Fresh Weight (mg) & Number of Leaves & Length $(\mathrm{cm})$ & Diameter (mm) \\
\hline \multirow{5}{*}{$1^{\text {st }}$ Year } & A & $3.66 \mathrm{~b}$ & $40.70 \mathrm{~b}$ & $2.30 \mathrm{~b}$ & $25.16 \mathrm{c}$ & $3.46 \mathrm{~b}$ \\
\hline & B & $5.58 \mathrm{ab}$ & $77.16 \mathrm{a}$ & $2.91 \mathrm{a}$ & $27.40 \mathrm{abc}$ & $5.34 \mathrm{a}$ \\
\hline & $\mathrm{C}$ & $6.41 \mathrm{a}$ & $85.00 \mathrm{a}$ & $2.83 \mathrm{a}$ & $29.71 \mathrm{a}$ & $4.84 \mathrm{a}$ \\
\hline & $\mathrm{D}$ & $5.83 \mathrm{ab}$ & $78.91 \mathrm{a}$ & $2.91 \mathrm{a}$ & $28.75 \mathrm{a}$ & $5.93 \mathrm{a}$ \\
\hline & Mean & 5.48 & 71.73 & 2.76 & 27.87 & 4.95 \\
\hline \multirow{5}{*}{$2^{\text {nd }}$ Year } & A & $6.58 \mathrm{a}$ & $78.75 a$ & $3.08 \mathrm{a}$ & $29.01 \mathrm{a}$ & $5.31 \mathrm{a}$ \\
\hline & B & $5.16 \mathrm{ab}$ & $72.08 \mathrm{a}$ & $2.75 \mathrm{ab}$ & $25.62 b c$ & $5.47 \mathrm{a}$ \\
\hline & $\mathrm{C}$ & $5.33 \mathrm{ab}$ & $74.33 \mathrm{a}$ & $2.83 \mathrm{a}$ & $28.60 \mathrm{ab}$ & $4.75 a$ \\
\hline & $\mathrm{D}$ & $5.10 \mathrm{ab}$ & $62.09 \mathrm{ab}$ & $2.81 \mathrm{a}$ & $27.74 \mathrm{abc}$ & $5.39 \mathrm{a}$ \\
\hline & Mean & 5.56 & 72.02 & 2.87 & 27.74 & 5.23 \\
\hline
\end{tabular}

Table 2. The seedling emergence characteristics in one and two-year seeds of four long-day onion varieties

\begin{tabular}{clccc}
\hline & & Emergence Rate (\%) & Emergence Time (d) & Vigor Index \\
\hline \multirow{6}{*}{$1^{\text {st }}$ Year } & A & $22.00 \mathrm{c}$ & 7.09 & $0.73 \mathrm{~b}$ \\
& $\mathrm{~B}$ & $85.50 \mathrm{ab}$ & 7.13 & $2.11 \mathrm{a}$ \\
& $\mathrm{C}$ & $88.25 \mathrm{ab}$ & 7.75 & $2.85 \mathrm{a}$ \\
& $\mathrm{D}$ & $95.50 \mathrm{a}$ & 8.69 & $2.43 \mathrm{a}$ \\
\hline \multirow{2}{*}{$2^{\text {nd }}$ Year } & $\mathbf{7 2 . 8 1 a}$ & $\mathbf{7 . 6 7}$ & $\mathbf{2 . 0 3 a}$ \\
& Mean & $80.00 \mathrm{ab}$ & 6.06 & $2.39 \mathrm{a}$ \\
& $\mathrm{A}$ & $79.75 \mathrm{ab}$ & 7.41 & $1.70 \mathrm{ab}$ \\
& $\mathrm{B}$ & $69.00 \mathrm{~b}$ & 7.52 & $1.79 \mathrm{ab}$ \\
& $\mathrm{C}$ & $24.75 \mathrm{c}$ & 6.914 & $0.66 \mathrm{~b}$ \\
\hline & $\mathrm{D}$ & $\mathbf{6 3 . 3 7 b}$ & $\mathbf{6 . 9 7}$ & $\mathbf{1 . 6 4 b}$ \\
\hline
\end{tabular}

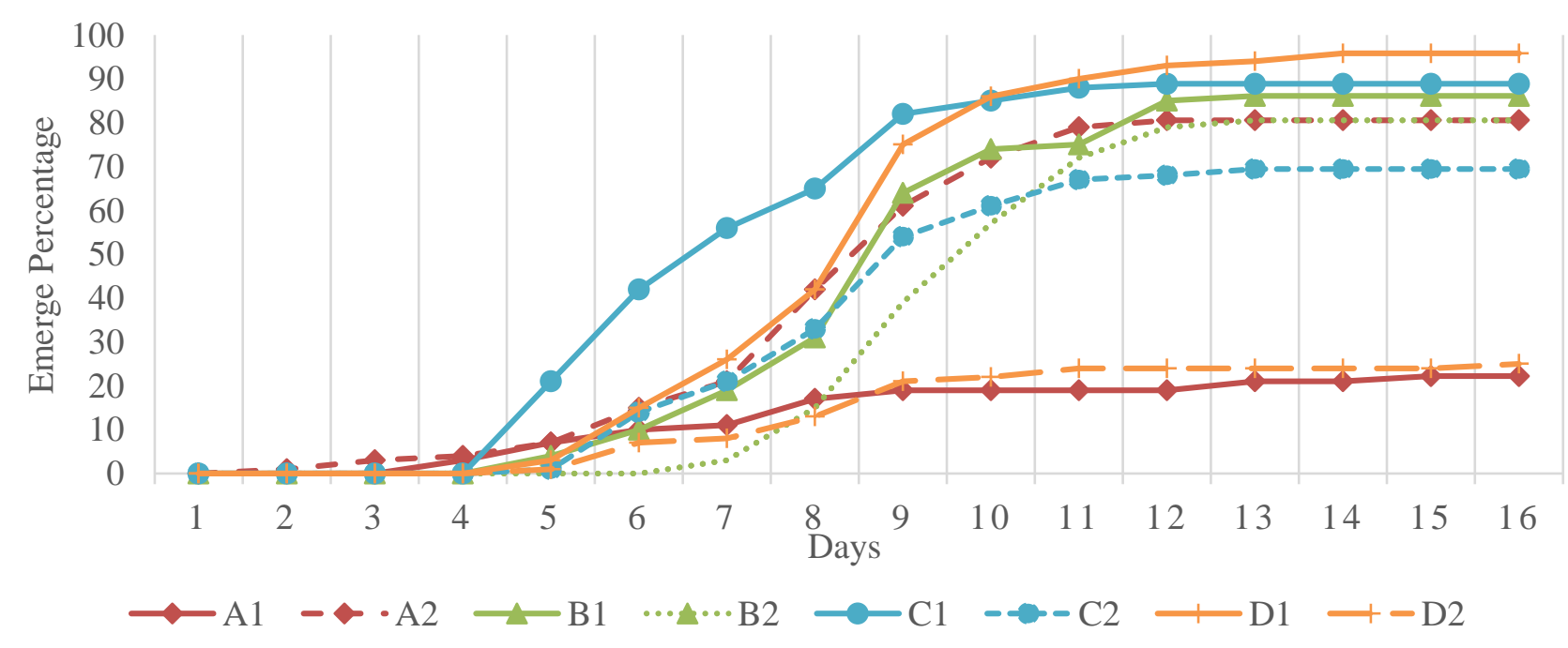

Figure 2. Seed emergence percentages by day 
In general, it was determined that seedling fresh and dry weight, emergence rate, and vigor decreased due to ageing in onion seeds (except variety A). This situation, namely the decrease in quality due to the rapid ageing of onion seeds, has been reported in previous studies (Rao et al., 2006; Ilbi and Eser, 2006; Demirkaya et al., 2010). Likewise, it was determined that the emergence rate and vigor index values of two-years seeds of D variety were very low. Possible reasons for this may be unsuitable environmental conditions in the seed production season and/or storage conditions. Seed quality and seed longevity are primarily governed and influenced by genetic factors and nowadaysthey are considered by the plant breeders as important traits (Selvi and Saraswathy, 2018). It is possible to classify varieties as good or poor according to their storability performance. In storage, beside the seed viability and vigor is regulated by many factors like seed moisture content, temperature, relative humidity, initial seed quality, physical and chemical composition of seed, storage structure, packaging materials, etc., also it could vary from species to species, and cultivars to cultivars (Doijode, 1995; Patel et al., 2017).Generally during storage, the seed viability and seed longevity is considerably influenced by key factors like the heritable genetic make-up of the varieties, initial seed quality, moisture content, relative humidity and temperature, provenance, the activity of organisms associated with seeds in storage, oxygen pressure and other factors such as direct sunlight on the seed, number of times and kind of fumigation, the effect of seed treatment, storage conditions in transit, and at the retailer's store and user's farm, etc. (Selvi and Saraswathy, 2018; Ashok et al., 2019). Even if the germination and vigor are good in seed harvest period, since onion seed loses its viability and vigor rapidly, the storage conditions are of great importance. In an experiment conducted by Geetanjali et al. (2019), onion seeds were storage three different conditions for 10 months (ambient condition, conditioned cold storage $\left(18-20^{\circ} \mathrm{C}, 45-50 \% \mathrm{RH}\right)$, commercial cold storage $\left(5-7^{\circ} \mathrm{C}, 65 \% \mathrm{RH}\right)$. The results exhibited that commercial cold storage was best for maintaining seed quality parameters. It has been expressed that the decline in seed germination and vigor related to storage conditions and duration could be due to a reduction in metabolic activity and enhancement in antioxidant activity. Also, Khan et al. (2004) suggested that the membrane integrity loss in relation to aging may be responsible for the decreased germinability, vigor.

\section{CONCLUSION}

In this study, it was determined that the length, diameter, weight of seedlings, and the number of leaves were not changed according to seed production year (one- or two-year seeds) but the emergence rate and vigor index of two-year seeds was lower than to one-year seeds, except A variety. Also, the emergence percentage and vigor index of two-year seeds of D varieties remarkably decreased. From those results could be concluded that post-harvest conditions may be effective on onion seed quality, and there may be seed quality differences among varieties.

\section{Conflict of Interest}

The article authors declare that there is no conflict of interest between them.

\section{Author's Contributions}

The authors declare that they have contributed equally to the article.

\section{REFERENCES}

Arin L, 2018. Tohum Depolama, Türktob, 26, 8-10. In Turkish.

Ashok GB, Doddagoudar SR, Vasudevan SN, Patil MG, Hosamani A, 2019. Evaluation of the Best Storage Methods for Maintaining Seed Quality of Onion. International Journal of Current Microbiology and Applied Sciences, 8(4): 325-336. 
Baslar G, Ilbi H, 2020. Do Seed Harvest Period and Drying Method Affect the Seed Quality and Yield in Onion? Acta Hortic. 1273, 323-328.

Brar NS, Kaushik P, Dudi BS, 2019. Effect of Seed Priming Treatment on the Physiological Quality of Naturally Aged Onion (Allium cepa L.) Seed. Applied Ecology and Environmental Research, 18(1): 849-862.

Brewster JL, 1994. Onion and Other Vegetable Alliums. Cambrige University Press, Cambridge, UK.

Demirkaya M, Dietz KJ, Sivritepe HO, 2010. Changes in Antioxidant Enzymes During Ageing of Onion Seeds. Notulae Botanicae Horti Agrobotanici Cluj-Napoca, 38(1): 49-52.

Doijode SD, 1995. Effect of Silica Gel and Storage Containers on Viability and Vigour in Onion. Seed Research, 18: $163-165$.

Dorna H, Jarosz M, Szopinska D, Szulc I, Rozinska A, 2013. Germination, Vigour and Health of Primed Allium cepa L. Seeds After Storage. Acta Sci. Pol., Hortorum Cultus, 12(4): 43-58.

Ellis RH, Roberts EH, 1981. The Quantification of Ageing and Survival in Orthodox Seeds. Seed Science \& Technology, 9, 373-409.

FAO, 2021. Statistics database. http://www.fao.org/faostat/en/\#data/QCL

Geetanjali C, Sangeeta IM, Prashant SM, Basavegowda A, Beladhadi RV, 2019. Effect of Storage Conditions on Seed Longevity of Onion (Allium cepa L.). International Journal of Current Microbiology and Applied Sciences, 8(2): 1897-1905.

Ilbi H, Eser B, 2006. The potential of Vigour Tests to Identify Differences in the Extent of Ageing in Onion Seeds. Seed Science and Technology, 34(3): 713- 718.

Khan M, Iqbal MJ, Abbas M, Raza H, Waseem R, Ali A, 2004. Loss of Vigour and Viability in Aged Onion (Allium cepa L.) Seeds. International Journal of Agriculture \& Biology: 6(4): 708-711.

Khokhar KM, 2018. Seed Viability and Germination, Part 1, Chapter 2, Onion: An Ancient Crop and Modern Practice- A Review. Noor Publishing, 608 pp.

Lorenz OA, Maynard DN, 1988. Knott's Handbook for Vegetable Growers (Third Edition). A Wiley-Interscience Publication, New York.

Mendiburu F, 2021. agricolae: Statistical Procedures for Agricultural Research. R Package Version 1.3-5. https://CRAN.R-project.org/package=agricolae" https://CRAN.R-project.org/package=agricolae

Mereddy R, Wu L, Hallgren SW, Wu Y, Conway KE, 2000. Solid Matrix Priming Improves Seedling Vigor of Okra Seeds. Proceedings of the Oklahoma Academy of Science, 80: 33-37.

Patel JB, Babariya CA, Sondarva J, Ribadiya KH, Bhatiya VJ, 2017. Effect of Storage Conditions, Packing Materials Nad Seed Treatments Viability and Seedling Vigour of Onion (Allium cepa L.) seeds. Journal of Applied and natural Science, 9(2): 1054-1067.

R Core Team, 2021. R: A Language and Environment for Statistical Computing. R Foundation for Statistical Computing, Vienna, Austria. URL https://www.R-project.org/

Rao RGS, Singh PM, Rai M, 2006. Storability of Onion Seeds and Effects of Packaging and Storage Conditions on Viability and Vigour. Scientia Horticulturae, 110(1): 1- 6.

Roberts EH, 1974. Storage Environment and the Control of Viability. In Viability of Seeds, E.H. Roberts (Eds.), pp.14-59, Chapman and Hall Ltd, London.

Selvi DT, Sarawathy S, 2018. Seed Viability, Seed Deterioration and Seed Quality Improvements in Stored Onion Seeds: A Review. The Journal of Horticultural Science and Biotechnology, 93: 1-7.

Sivasakthi S, Renugadevi J, 2020. Appraisal of Storage Potential of Onion cv. CO (On) 5 Seeds Under Carbon Dioxide and Ambient Storage Condition. Journal of Pharmacognosy and Phytochemistry, 9(5): 925-932. 